University of Nebraska - Lincoln

DigitalCommons@University of Nebraska - Lincoln

PreColumbian Textile Conference VIII /

Jornadas de Textiles PreColombinos VIII (2019)

Centre for Textile Research

6-2020

\title{
Ancient Peruvian textiles in the Vatican Museums and their link to the Musée du Trocadéro collections
}

Jean-François Genotte

Follow this and additional works at: https://digitalcommons.unl.edu/pctviii

Part of the Art and Materials Conservation Commons, Fiber, Textile, and Weaving Arts Commons, Indigenous Studies Commons, Latin American Languages and Societies Commons, Museum Studies Commons, and the Other History of Art, Architecture, and Archaeology Commons

This Article is brought to you for free and open access by the Centre for Textile Research at DigitalCommons@University of Nebraska - Lincoln. It has been accepted for inclusion in PreColumbian Textile Conference VIII / Jornadas de Textiles PreColombinos VIII (2019) by an authorized administrator of DigitalCommons@University of Nebraska - Lincoln. 


\title{
14
}

\section{Ancient Peruvian textiles in the Vatican Museums and their link to the Musée du Trocadéro collections}

\author{
Jean-François Genotte \\ Assistant Registar, Ethnological Collections \\ The Vatican Museums, Vatican City State, jf.genotte@scv.va
}

\begin{abstract}
The Vatican Museums keep a small collection of about sixty textile fragments mostly Lambayeque, Chimu and Chancay dating back to Late Intermediate Period. Unfortunately, the archaeological provenance of these items is not known. This paper offers a first overview of the history of the collection, describing its contents and, in more details, its most interesting fabrics. We will then suggest that some fragments of the Vatican collection might have been part of textiles once kept in the Musée du Trocadéro, and nowadays preserved in the Quai Branly Museum in Paris.
\end{abstract}

Keywords: Vatican Museums, Musée du Trocadéro, Rodolphe Pfister, Fritz Iklé, Lambayeque, Chimu, Chancay, monkey, bicephalic serpent, feathered crescent-shape headdress, comma shaped eyes, Staff-bearing Deity

\section{Resumen}

Los Museos del Vaticano conservan una pequeña colección de unos sesenta fragmentos textiles, en su mayoría Lambayeque, Chimú y Chancay, que datan del Periodo Intermedio Tardío. La procedencia arqueológica de estas piezas lamentablemente no se conoce. Por primera vez, presentamos la historia de la colección, sus contenidos y las piezas textiles más interesantes. Proponemos entonces que algunos fragmentos de la colección del Vaticano probablemente podrían haber sido parte de tejidos, previamente conservados en el Museo del Trocadero, y hoy expuestos en las colecciones del Musée du Quai Branly en París.

Palabras claves: Museos del Vaticano, Museo del Trocadero, Rodolphe Pfister, Fritz Iklé, Lambayeque, Chimú, Chancay, mono, serpiente bicéfala, tocado de plumas en forma de media luna, ojos alados, Deidad con báculos

\section{Résumé}

Les Musées du Vatican conservent une petite collection d'une soixantaine de fragments de tissus, pour la plupart Lambayeque, Chimu et Chancay, datés de la Période Intermédiaire Récente. La provenance archéologique de ces pièces n'est malheureusement pas connue. Pour la toute première fois, nous présentons l'histoire de la collection, son contenu et les exemplaires textiles les plus intéressants. Nous proposerons ensuite comment certains fragments de la collection du Vatican auraient probablement pu faire partie de tissus, autrefois conservés au Musée du Trocadéro, et aujourd'hui présents dans les collections du Musée du Quai Branly - Jacques Chirac à Paris.

Mots-clés : Musées du Vatican, Musée du Trocadéro, Rodolphe Pfister, Fritz Iklé, Lambayeque, Chimu, Chancay, singe, serpent bicéphale, coiffe en plumes en forme de demi-lune, yeux en forme de virgules, Divinité aux bâtons

Photographs Foto Copyright (c) Governatorato S.C.V. - Direzione dei Musei: Jean-François Genotte (Fig. 1, 2); Alessandro Bracchetti (Fig 3 to 12).

DOI: $10.32873 /$ unl.dc.zea.1215

Published in PreColumbian Textile Conference VIII / Jornadas de Textiles PreColombinos VIII, ed. Lena Bjerregaard and Ann Peters 


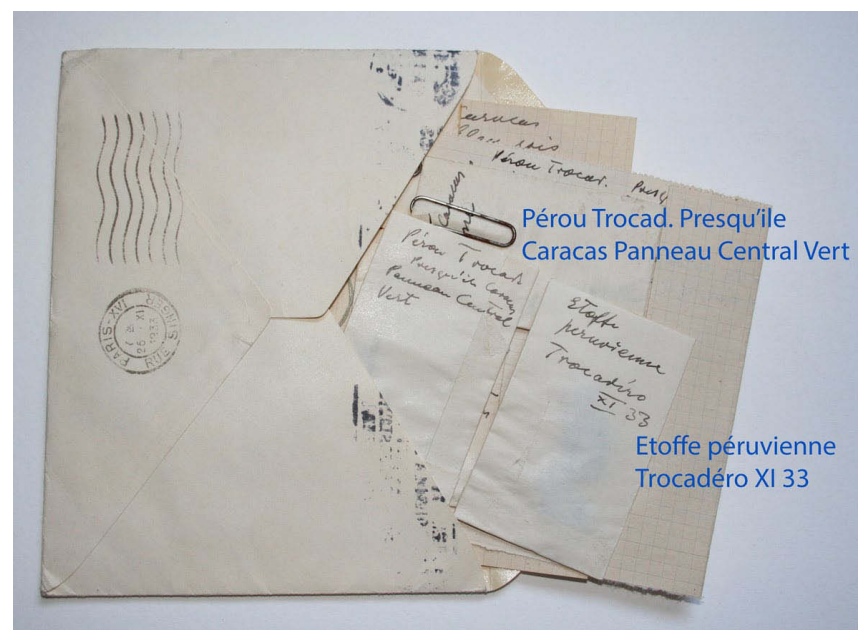

Figure 1. Notes on small sheets found with the Vatican fragments that suggest the provenience from the Musée du Trocadéro in Paris. Vatican Museums, Vatican City. Foto Copyright (c) Governatorato S.C.V. - Direzione dei Musei.

\section{The history of the collection}

In the Vatican Museums, there is a small collection of textiles from ancient Peru. While we cannot compare this small series of items to the large collections of pre-Columbian textiles of prestigious European and American museums, both in terms of number of pieces and aesthetic value, nonetheless it has a curious history. The small group of ancient Peruvian textiles, indeed, is part of a larger collection, the Pfister Collection, consisting of over 1600 textiles of oriental origin: most of the items come from Sasanid Iran, from Pharaonic, Fatimid and Coptic Egypt, and from Palmira. The Pfister Collection is part of the Tapestry and Textiles (Arazzi e Tessuti) department of the Vatican Museums.

The Peruvian Vatican collection consists of sixty-four small-sized fragments from twenty-six different textiles ${ }^{1}$, four cords of camelid fibers ${ }^{2}$ and nineteen samples of camelid fibers and cotton yarns of different colors (red, pink, gold and mustard yellows, green, blue, purple) ${ }^{3}$. These items are the only pre-Hispanic textile fragments preserved in the Vatican Museums, except for one Wari feathered panel (MV 103872) and three cotton fragments sewn together decorated with geometric patterns (MV 104358), perhaps of Wari style, preserved in the Ethnological department (Museo

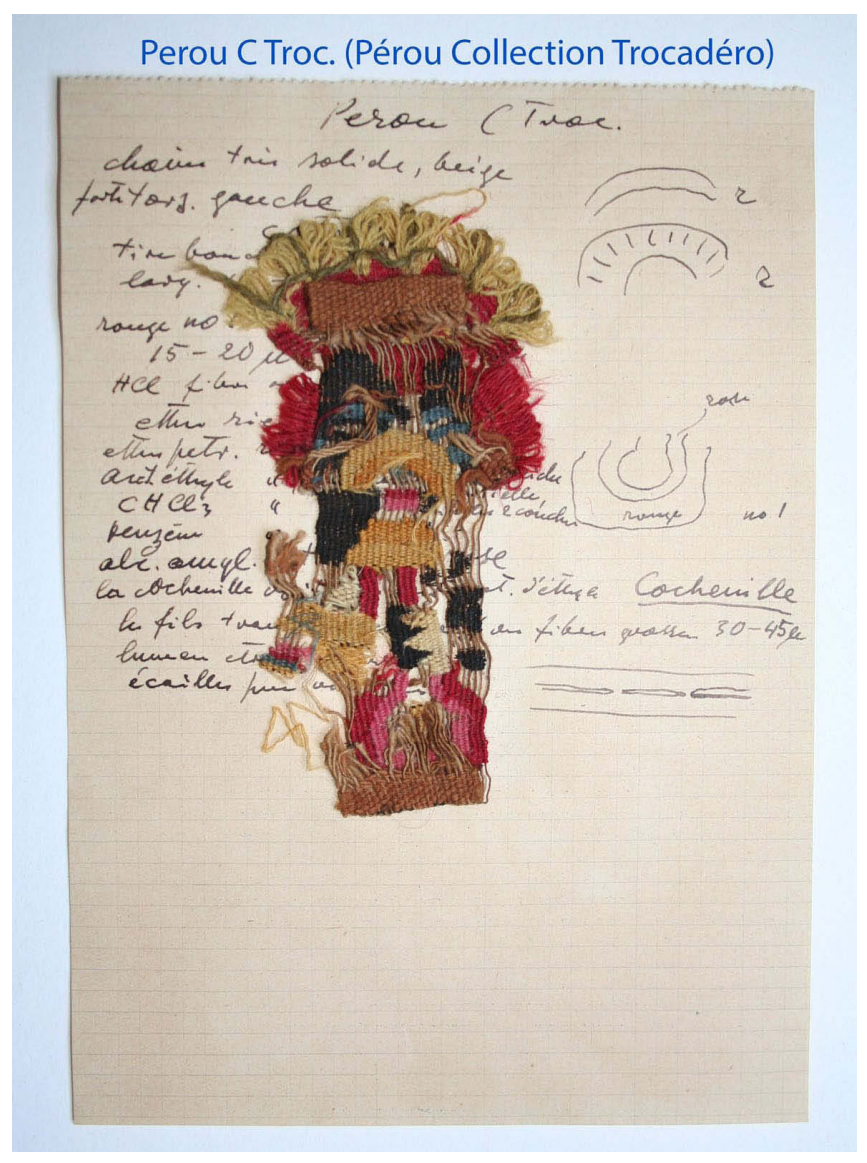

Figure 2. Notes found with fragment MV 63652 that suggest its provenience from the Musée du Trocadéro and show Pfister's interest to analyze dyes and textiles. Vatican Museums, Vatican City. Foto Copyright (C) Governatorato S.C.V. - Direzione dei Musei.

Etnologico "Anima Mundi"). The archaeological context of these items collected between the twenties and thirties of last century by Rodolphe Pfister (1867-1955), a Swiss chemist specializing in the study of the ancient textiles of Asia and the Near East, is unfortunately unknown.

As far as we know, Pfister, driven by a specific scientific interest in the chemical study of dyes, collected many fragments and textile samples from many countries, which he obtained through his large network of friends and acquaintances in museums and institutions worldwide.

In $1958^{4}$, the Pfister Collection was donated to the Vatican Apostolic Library by provisions of Rodolphe Pfister's last will; subsequently, in October 1999, it became integral part of the Vatican Museums ${ }^{5}$. Several notes (fig. 1, 2) written

1. MV 62407, MV 63625, MV 63626, MV 63643 to MV 63662, MV 63777, MV 66991, MV 67012.

2. MV 63627 to MV 63629, MV 63642.

3. MV 63630 to MV 63641, MV 63776, MV 63778 to MV 63783.

4. Legacy of Rodolphe Pfister to the Vatican Apostolic Library, 1958 (ASMV).

5. The collection moved to the Vatican Museums from the Vatican Apostolic Library according to the provisions in the Rescriptum of John Paul II, August 1, 1999. 
on small sheets ${ }^{6}$ have been found with three textiles ${ }^{7}$ and with most of the cords and samples of yarns ${ }^{8}$. Those notes suggest that before the items were collected by Pfister, they were kept at the Musée du Trocadéro ${ }^{9}$ in Paris, and have been most likely given to him in November $1933^{10}$. The fragment MV 63649 was donated to Pfister by the Swiss collector Fritz Iklé ${ }^{11}$ in November $1927^{12}$. We also know from a letter written in December $1936^{13}$ that Pfister planned a visit to the Musée du Trocadéro in order to see the Peruvian textiles of the Parisian collection.

Documents of the Pfister Archive ${ }^{14}$ that are kept in the Vatican Museums provide scarce clues as far as dating, origin, culture and description of the fragments in the collection are concerned. We do not even know if these items came from official archaeological excavations or lootings in necropolis. Origin of the items can be attributed to the Peruvian area thanks to some notes written in French that were found with some of the textile fragments. They provide the following (and unambiguous) information: "Peru"15, "Peruvian textile"16 and "Peruvian mummy"17.

Other notes indicate that some samples of yarns ${ }^{18}$ and the fragment MV 63777 are Peruvian and came from the Paracas Peninsula ${ }^{19}$; it seems that they were taken from the central panel of a large textile, of which we know nothing. Some letters ${ }^{20}$ kept in the Pfister Archive, however, show that Pfister sought to analyze dyes used in the tincture of pre-Columbian Peruvian textiles; therefore, he was interested in purchasing Peruvian textiles and wishful to visit the Musée du Trocadéro to examine Peruvian textiles and discuss with Raoul D'Harcourt.

Between 2008 and 2009, the textile fragments of the Pfister Collection have been carefully restored, under the responsibility of the Tapestries and Fabrics restoration laboratory of the Vatican Museums.

\section{The textile collection}

Most of the Peruvian textile fragments of the Pfister Collection date back to the Late Intermediate Period (900-1476 $\mathrm{AD}$ ) and almost all come from the North and Central coasts of Peru ${ }^{21}$. Three fragments ${ }^{22}$ seem to be dated about 8oo$1200 \mathrm{AD}$, between the end of the Middle Horizon and the

6. These sheets are preserved, together with their corresponding items, in the collections of the Vatican Museums.

7. MV 63626, MV 63650, MV 63652.

8. MV 63627 to MV 63642, MV 63776, MV 63778 to MV 63781, MV 63783.

9. The Musée du Trocadéro, or Musée d'ethnographie du Trocadéro (Ethnographic Museum of the Trocadéro), was the first anthropological museum in Paris, founded in 1878 as the Musée ethnographique des missions scientifiques (Ethnographic Museum of Scientific Expeditions) and housed in the Trocadéro Palace (1878-1935), then demolished in 1935. In 1937, it took the name of Musée de l'Homme (Museum of Mankind), and part of its collections were relocated in the Palais de Chaillot just built on the same site (1935-1937). In 2004, the vast majority of the collections preserved in the Palais were moved to the new Quai Branly Museum, opened in 2006 and renamed Musée du quai Branly - Jacques Chirac in 2016.

10. At the beginning of the twenty century private collectors, antique dealers and museum institutions used to cut fragments from pre-Columbian textiles to buy, sell or donate them to other museums and collectors (Bjerregaard et al. 2017, p. 33).

11. Fritz Iklé (1877 1946) was the younger son of Leopold Iklé, an important manufacturer, merchant and textile collector from St. Gallen (Switzerland). He formed its own collection from the early 1920s. During the same period, he became interested in the textile collection from ancient Peru preserved in the Musée du Trocadéro in Paris, and published his research on this topic in 1930: Über Alt-Peruanische Stickereien des Trocadéro, Paris. Mitteilungen der Ostschweiz. Geogr. Commerz. Gesellschaft, St Gallen (Iklé 1930; http://www.textilmuseum.ch/textilmuseum). 12. This date is written on an envelope containing the fragment MV 63649.

13. R. Pfister to H. Delbrueck, letter, 2 December 1936, ASMV, Carte Pfister, busta 24, fascicolo Europa I.

14. It is a significant amount of archive material, preserved in the Historical Archive of the Vatican Museums (ASMV): twenty-one boxes containing various notes by Pfister, two boxes of photos and a rich correspondence filed in six boxes, made up of hundreds of letters exchanged by Pfister with many scholars between 1920 and 1940 .

15. Spelled as "Pérou" on the sheets found together with the fragments MV 63626, 63650 and 63652.

16. Written as "Étoffe péruvienne" on the envelope containing the fragment MV 63649.

17. The note, relating to the MV 63630 to MV 63641 yarns, is written on a piece of paper and reads as follows: "Trocadéro 15 XI 33 / Échantillon de fils de différentes couleurs provenant de pelotes de fil trouvées dans une momie péruvienne"; that is: "Trocadéro 15 XI 33 / Sample of yarns of different colors from yarn balls found in a Peruvian mummy".

18. MV 63776, MV 63778 to MV 63783.

19. In the notes it is erroneously reported "Presqu'île de Caracas", but probably the site referred to it is the Paracas peninsula and not that of Caracas, which indeed does not exist in Peru.

20. R. Pfister to Fortunato L. Herrera, letter, 23 December 1933; R. Pfister to Fortunato L. Herrera, letter, 27 April 1934; R. Pfister to H. Delbrueck, letter, 2 December 1936 (ASMV, Carte Pfister, busta 24, fascicolo Europa I).

21. MV 63625, MV 63626, MV 63644, MV 63645, MV 63647, MV 63648, MV 63650, MV 63651, MV 63652, MV 63653, MV 63654, MV 63655, MV 63656, MV 63657, MV 63658, MV 6366o, MV 63662.

22. MV 62407, MV 63659, MV 67012. 
beginning of the Late Intermediate Period, while only one item MV 63649 may have been woven between the end of the Late Intermediate Period and the beginning of the Middle Horizon (1400-1500 AD). As far as two more items are concerned (MV 63661, MV 63777), they are probably of coastal origin, although it is not possible to propose a precise dating.

Four textiles ${ }^{23}$ have been attributed to Chancay culture, four items ${ }^{24}$ to Chimu culture, while a larger number of fragments are possibly of Lambayeque or Lambayeque/Chimu style $^{25}$. The fragment MV 63649 is probably of Chimu/Inca style while a last item (MV 63646), hardly identifiable, is attributed to one of the cultures of the Highlands or of the Coast between the Middle Horizon and the Recent Horizon (6oo- $1500 \mathrm{AD}$ ). It was not possible to attribute each of the Vatican fragments to a specific type of garment, because they are all very small. However, most of these could be fragments of borders ${ }^{26}$, decorative bands ${ }^{27}$ or appliqué decorative elements ${ }^{28}$.

As for the iconographic repertoire used in the decoration of the Vatican fragments, there is a remarkable homogeneity of motifs typical of the Lambayeque, Chimu and Chancay cultures; those patterns reflect a worldview based on a common religion, in turn closely connected to agriculture and to the resources and the economy of the coast, so important for local populations. First, there is a recurring presence of the sea in the form of stylized depictions of fish ${ }^{29}$ (fig. 9, 10), waves ${ }^{30}$ and birds ${ }^{31}$ (fig. 11). Other typical coastal motifs are anthropomorphic figures (fig. 4, 6, 9, 10) that represent deities, priests (shamans) and high-ranking dignitaries, depicted in frontal position, sometimes with a large elaborate crescent-shaped feather headdress or with a headdress adorned with a snake-shaped or a bird-shaped end double plume. The figures are dressed in fine clothing and often recognizable by their insignia of rank: ceremonial staffs or scepters and neckpieces or gorgets ${ }^{32}$. Less frequent, but also present in the Vatican textiles' decoration, are motifs such as the monkey (fig. 3), the flower (MV 63626) (fig. 5), the two-headed snake (MV 63625, MV 63662, MV 63647), the feline and the diamond (MV 63645, MV 63648, MV 63658) (fig. 12). The checkerboard pattern that decorates the two fragments of the probably Chimu ${ }^{33}$ or Chimu-Inca style item MV 63649, dating from ca. 1400-1500 AD, could suggest that they belonged to a tunic worn by a member of the local aristocracy, perhaps of military rank, or in connection with the latest Inca provincial administration.

We decided not to present and describe all the fabrics of the Vatican collection (see below, conclusions), but only some of those that have the most elaborate and interesting iconographic motifs, and some of the fragments of the collection that might have been part of textiles once kept in the Musée du Trocadéro, and nowadays preserved in the Quai Branly Museum in Paris. The main intent was so to dwell above all on the Vatican textiles associated with the Musée du Trocadéro collections.

This beautiful border fragment (fig. 4) is one of the nicest items of the collection. The warp yarns are cotton 2Zplied, while the weft yarns are camelid fiber plied $2 S$. It features a large green frontal male figure centrally placed inside a red rectangular panel, that wears a yellow and olive-green feathered headdress trimmed with green feathers; two earrings; and a green short tunic decorated with blue and yellow geometric patterns, probably metal plaques ${ }^{34}$, with a contrasting patterned band at the bottom ${ }^{35}$. The geometric motifs that we also find on the legs could also be interpreted as body paintings or tattoos because the short tunics worn by the men left their legs bare. These motifs could reproduce small spots therefore suggesting the spotted skin of a feline, perhaps the jaguar ${ }^{36}$, ubiquitous animal in Andean mythology that is associated with rain, agricultural production, sacrifice and fertility ${ }^{37}$.

23. MV 63643, MV 63644, MV 63645, MV 63657.

24. MV 63625, MV 63648, MV 63658, MV 66991.

25. MV 62407, MV 63626, MV 63647, MV 63650, MV 63651, MV 63652, MV 63653, MV 63654, MV 63655, MV 63656, MV 63659, MV 6366o, MV 63662, MV 67012.

26. MV 62407, MV 63625, MV 63648, MV 63658, MV 66991, MV 67012.

27. MV 63626, MV 63650, MV 63659.

28. MV 63647, MV 63651, MV 63652, MV 63653, MV 63654, MV 63655, MV 63656, MV 6366o, MV 63662.

29. MV 62407, MV 63625, MV 67012.

3o. MV 63648, MV 63658.

31. MV 62407, MV 63625, MV 63647, MV 63648, MV 63662, MV 67012.

32. MV 62407, MV 63647, MV 63650, MV 63662, MV 66991, MV 67012.

33. On the use of this motif in Chimu style fabrics, see King 202a, p. 140; Rowe 1984, pp. 31, 95-119.

34. For tunics with metal plaques, see Fleitman and Baginski 2017, pp. 351 (fig. 3-4), 353 (fig. 7); Rowe 1984, pp. 151-154 (fig. 148, 150, 152, pl. 23); Stone-Miller 1994a, p. 128, pl. 38; Jiménez Borja et al. 1987, pp. 244, 251.

35. This band surely represents the tapestry borders on surviving tunics (Bjerregaard 2016, p. 17).

36. Lambayeque (900-1100 AD) and Central coastal textiles (1000-1500 AD) preserved in the Ethnological Museum of Berlin are decorated with jaguars with spotted skin (Bjerregaard et al. 2017, pp. 38, 96-97, 99, 140).

37. Laurencich Minelli 1984, p. 24; Petrucci et al. 1982, pp. 17, 20. 


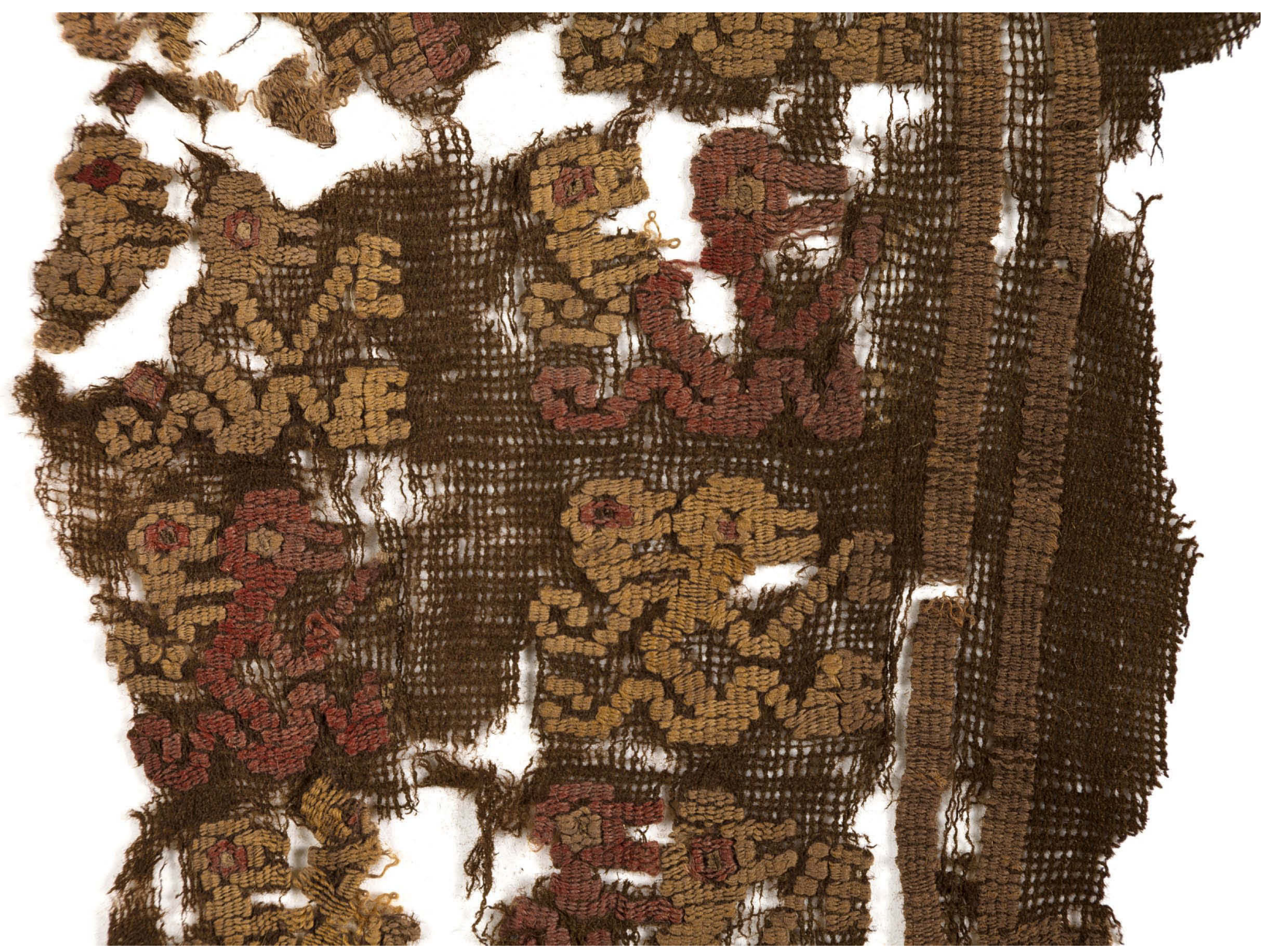

Figure 3. Fragment (detail) with depiction of monkeys. Chancay, Central Coast, Peru, 1000-1200 AD. Cotton (2 warps: S-plied, 1 weft: S-plied), camelid fiber (1 weft: Z-plied); gauze, brocade, 31 x $16 \mathrm{~cm}$. MV 63643, Vatican Museums, Vatican City. Foto Copyright (C) Governatorato S.C.V. - Direzione dei Musei.

The large figure presents some features considered characteristic of Lambayeque imagery: an hourglass nose ornament, spectacled eyes (or the so called "comma shaped eyes ${ }^{38}$ ), a tight neckpiece under the chin - reaching up the ears -, and holds a scepter or a ceremonial staff 39 in his right hand, and a trophy head with falling hair in his left hand. The figure hands and feet, shown in profile, are common to many figures depicted in Northern and Central Coastal textiles dating to the Late Intermediate Period ${ }^{40}$. The figure is depicted with naked feet or wears non-functional shoes with pointed toes ${ }^{41}$.

The image of a figure with an elaborate headdress and a staff in each hand can be found in Chavin art ${ }^{42}$ as well as in Wari and Tiwanaku art ${ }^{43}$. It is not clear if the Lambayeque

38. Figures with comma shaped eyes or upturned comma eyes are typical of the Lambayeque style (Bjerregaard 2016, p. 8, fig. 6, 15, 17; Bjerregaard et al. 2017, pp. 33, 119 (VA 54885), 120 (VA 54886), 121 (VA 54888); Medina Castro et al. 2005, p. 96). According to Young-Sánchez (1994, pp. 43-44, fig. IV.1) the comma shaped eyes may refer to the "mythical" status of the figure.

39. Scepters and ceremonial sticks of wood and metal, sometimes covered with gold and silver and showing a zoomorphic or anthropomorphic upper part have been found in Lambayeque and Chimu tombs belonging to high-ranking individuals (Biordi 2005, p. 89; Jiménez Borja et al. 1987, pp. 269-270; Fleitman and Baginski 2017, p. 354 (fig. 9); Wester La Torre 2013, pp. 108, 110 (fig. 1), 114).

40. See Amano and Tsunoyama 1979, pp. 52 (fig. 42), 68 (fig. 61), 103 (fig. 111); Desrosiers and Pulini 1992, pp. 149 (fig. 88), 150 (figg. 89, 90); Jiménez Díaz 2009, pp. 169 (fig. 119), 170 (fig. 120), 175-176 (fig. 123); Laurencich Minelli 1984, pp. 55 (fig. 42), 111 (fig. 119); Rowe 1984, pp. 71 (pl. 9), 120-121 (pl. 18), 124-128 (fig. 109-117), 129 (pl. 19), 134-135 (fig. 128-129); Stone-Miller 1994a, pp. 128-129 (pl. 38), 165-167 (pl. 6o). 41. Specimens of these shoes covered with silver plaques have been found in Chimu aristocratic tombs (Fleitman and Baginski 2017, pp. 353, 354 (fig. 9); Stone-Miller 1994a, pp. 134-135 (pl. 42).

42. See Hoces de la Guardia Chellew et al. 2007, p. 25; Burger 1992, fig. 147-155.

43. See Bjerregaard et al. 2017, pp. 25 (fig. 1a), 26 (fig. 1b); Jiménez Díaz 2009, pp. 145-148 (fig. 96-99); Lavallée and Lumbreras 1985, pp. 220227 (fig. 200-204), 268 (fig. 241), 274 (fig. 247); Stone-Miller 1994b, pp. 34-35, 37 (fig. III.7). 


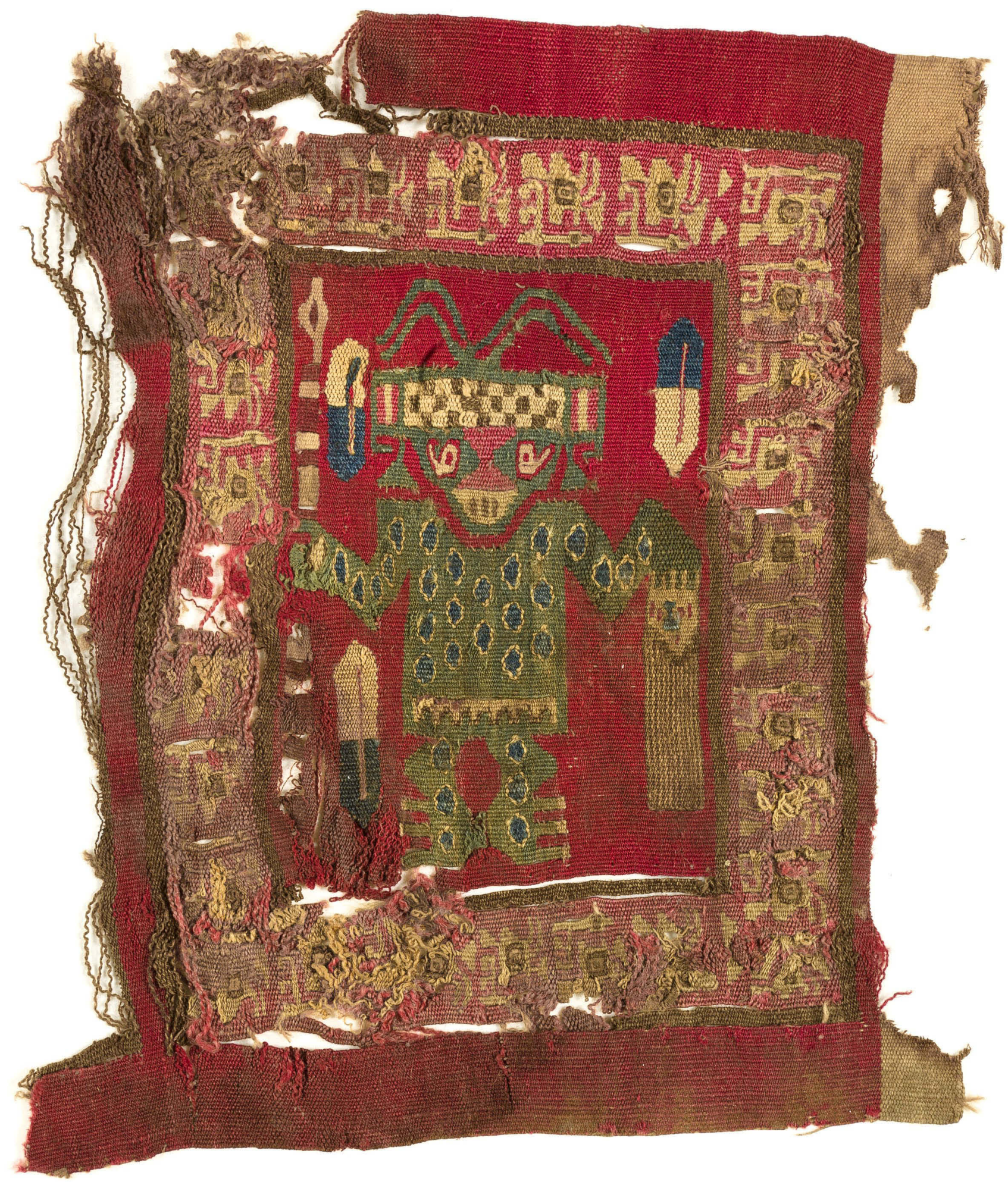

Figure 4. Border fragment with depiction of figures. Chimu, North Coast, Peru, 900-1300 AD. Cotton (warp: 2Z-plied), camelid fiber (weft: 2S-plied); tapestry, 23.5 x 18.5 cm. MV 66991, Vatican Museums, Vatican City. Foto Copyright (C) Governatorato S.C.V. - Direzione dei Musei. 
figure owes something to these earlier examples or not ${ }^{44}$. Some scholars proposed that the Lambayeque figure would be a coastal re-interpretation of the Staff-bearing Deity, an iconographic model introduced during the Wari occupation of the North Coast of Peru in the Middle Horizon. Others identified the figure with Naymlap, the legendary Lambayeque/Sicán ruler and conqueror who came from the sea ${ }^{45}$. Later, in the Chimu culture, the figure of Tacaynamo, the mythological founder of the Chimu dynasty, would have been inspired to the preceding Lambayeque figure, another iconographic influence of Lambayeque on Chimu culture ${ }^{46}$.

Recently, it has been proposed that the image of the Principal Deity of Lambayeque was based on, and developped after, the Andean bear (Tremarctos ornatus), more commonly known as the spectacled bear. The spectacled eyes (or the so called "comma shaped eyes") may have been inspired by the double line around the bear's eyes, while the hourglass nose and the neckpiece that looks like the white collar on the chest of the animal are also represented 47 .

It is tempting to suggest that this figure in the Lambayeque iconography is meant to depict Naymlap, while it is not sure at all that this is so. In any case, it is certainly an image of power ${ }^{4}$.

We suggest that the central figure of the Vatican fragment inv. 66991 is inspired to earlier depictions of the Wari Staff-bearing Deity, well represented by some carvings on the Sun Gate ${ }^{49}$ in Tiwanaku.
The red panel that contains the frontal figure presents a frame decorated with small yellow stylized figures, standardized in their design; they are in profile, depicted with an elaborate headdress and a ceremonial staff in hand. This decorative panel, with smaller figures arranged around a bigger central one, is typical of the Chimu iconography and can be also found on architectural friezes of raw brick of important ceremonial buildings ${ }^{50}$ as well as on tapestries ${ }^{51}$

Similar small figures are arranged in rows on the Sun Gate, apparently representing the attendants of the central frontal deity ${ }^{52}$. We may therefore assume that people wearing this picture on a tunic declared themselves as priests or administrators; in this way, they claimed a relation to a creator deity possibly fused with the state authority ${ }^{53}$. In my opinion, the central figure could depict an important divinity of the Lambayeque or the Chimu pantheon, or maybe one of her high-ranking priest.

The three large hexagonal motifs drawn in blue and yellow around the figure seem to represent stylized feathers ${ }^{54}$, a decorative pattern very popular along the North and Central Coasts between Late Intermediate Period and Late Horizon, especially in the Chimu, Chancay and Inca cultures. The motif of the feather could have an emblematic connotation and refer to political and territorial powers, since feathers were usually symbols of prestige among the coastal populations of pre-Columbian Peru.

Six other fabrics, similar in iconography and style to the Vatican item inv. 66991, can be found at the Museo Civico

44. Bjerregaard 2016, p. 14 .

45. Bjerregaard 2016, p. 14; Bjerregaard et al. 2017, p. 36; Jiménez Borja et al. 1987, p. 172; Fleitman and Baginski 2017, p. 350; Lavallée and Lumbreras 1985, pp. 275-276; Medina Castro et al. 2005, p. 96; Wester La Torre 2013, pp. 108-115.

46. Laurencich Minelli 1984, pp. 55 (fig. 42), 110 (fig. 118); Bjerregaard et al. 2017, pp. 124-125; Jiménez Borja et al. 1987, pp. 172, 174; Hoces de la Guardia Chellew et al. 2007, p. 75; Fleitman and Baginski 2017, p. 354; Lavallée and Lumbreras 1985, pp. 275, 297; Medina Castro et al. 2005, pp. 97-98; Rowe 1984, pp. 16, 66 (pl. 8), 70-72 (fig. 45-46, pl. 9); Stone-Miller 1994a, pp. 165-167 (pl. 6o); Young-Sánchez 1994 , p. 45. 47. Fleitman and Baginski 2017.

48. Bjerregaard 2016, p. 14 .

49. The Sun Gate is the most famous monument of the Tiwanaku culture. It is a monolithic gateway in andesite $3.80 \mathrm{~m}$ wide and $2.70 \mathrm{~m}$ high located on the large Kalasasaya's courtyard, one of the most important ceremonial buildings of the archaeological site of Tiwanaku. One face of the lintel is carved with a large central figure surrounded by three rows of eight winged characters, symmetrically arranged to the right and left; they are kneeling, hold distinct scepters and show other attributes specific to each of the overlapping rows (Bjerregaard et al. 2017, p. 25 (fig. 1a); Kolata 2004, pp. 800-801 (figg. 1186-1187); Lavallée and Lumbreras 1985, pp. 220-223 (figg. 200, 202)).

50. See Desrosiers and Pulini 1992, p. 22; Schaedel 1966, pp. 384-386, 390-391, 399-422.

51. See Hoces de la Guardia Chellew et al. 2007, p. 75; D’Harcourt 1934 [2008], p. 131 e (pl. XXVI); Desrosiers and Pulini 1992, p. 149 (fig. 88 ); Jiménez Díaz 2009, pp. 175-176 (fig. 123); MQB inv. 71.1878.2.578).

52. According to the Wari and Tiwanaku iconographic codes, these figures were always represented in profile to emphasize the hierarchical relationship with the main divinity (Bjerregaard et al. 2017, pp. 25 (fig. 1a), 26 (fig. 1b); Desrosiers and Pulini 1992, p. 20; Isbell 1988, p. 177).

53. Stone-Miller 1994b, p. 35.

54. See Amano and Tsunoyama 1979, pp. 35 (fig. 22), 102 (fig. 109), 192 (fig. 224), 202, 214; Bjerregaard et al. 2017 , p. 132 (VA 59900 a); Jiménez Borja et al. 1987, pp. 138, 215, 219; Hoces de la Guardia Chellew et al. 2007, p. 69; D'Harcourt 1934 [2008], p. 142, tav. LXXII (fig. 1-2); Jiménez Díaz 20o9, pp. 263, 334; MQB, inv. 71.1933.0.271.116 X, inv. 71.1933.0.271.117 X, inv. 71.1947.0.5.694 X; Rowe 1984, pp. 76, 78-80 (fig. 54-56, pl. 11), 92; Stone-Miller 1994a, p. 149. 
Archeologico Etnologico in Modena ${ }^{55}$, at the Ethnologisches Museum in Berlin ${ }^{5}$ (four items), at the Musée de l'Homme in Paris ${ }^{57}$ and at the Museum of the Americas in Madrid ${ }^{8}$.

\section{The Vatican Museums collection and its link with the Quai Branly Museum}

During the analysis of the Peruvian textiles in the Vatican collection, we found a remarkable similarity between fourteen Vatican items ${ }^{59}$ and some fabrics ${ }^{60}$ kept in the Quai Branly Museum in Paris. At the beginning of our paper, when discussing the origin of the Pfister Archive, we said that some Peruvian fragments of the Pfister Collection came precisely from the Musée du Trocadéro ${ }^{61}$. Unfortunately, we know practically nothing about the context of archaeological discovery and the historical course of the textiles preserved today in the Quai Branly Museum. Our research carried out in the Centre de Documentation et d'Archives of the aforementioned museum, only enabled us to discover that these textiles passed successively from the Musée du Trocadéro to the Musée de l'Homme, then to the Quai Branly Museum. We do know, however, that some of the Quai Branly fabrics similar to the Vatican textile fragments were donated in $1914^{62}$ and in $1933^{63}$ to the Trocadéro by Doctor Édouard Vergne $^{64}$. Based on these data, we suggest that the Vatican fragments could have been parts of textiles previously preserved in the Musée du Trocadéro, and now in the collection of the Quai Branly Museum.

We find clear evidence of this Parisian origin in two fragments of a decorative band with flower motifs (MV 63626) (fig. 5), eight fragments depicting anthropomorphic figures and ceremonial objects ${ }^{65}$ (fig. 6, 7, 8), two fragments with figures (MV 67012, MV 62407) (fig. 9, 10), a fragment with bird motifs (MV 63659) (fig. 11) and twelve small-sized fragments depicting geometric patterns (MV 63645) (fig. 12).

These two fragments of a Lambayeque or Lambayeque/ Chimu decorative band feature flower motifs made up of corollas with coloured stripes alternating with the pistil of another color, and tied together by a narrow band of beige yarns (fig. 5). The floral decoration is created by a bouclé effect through the untying of the wefts. The warp yarns are cotton S-spun, while the weft yarns are camelid fiber plied $2 S$.

The Vatican fragments inv. 63626 are identical in design, iconography and style to fragments of floral stripes that form part of a nowadays incomplete Lambayeque/Chimu textile preserved in the Quai Branly Museum in Paris ${ }^{66}$. The Paris fragments, however, show an idea of how the whole fabric was supposed to be. It features four decorative floral bands that act as a frame containing a composition of fourteen small figures ordered in three horizontal rows bordered internally by a double floral gallon. A fringe ends the lower edge of the item. The figures and the floral bands were probably first woven separately, then sewn and applied to the textile. The two Vatican band fragments as well as the Parisian fragments had probably both a function of attached decorative elements.

Fragment MV 63647 (fig. 6) is one remarkable example of the eight ${ }^{67}$ Lambayeque or Lambayeque/Chimu appliqué fragments depicting both anthropomorphic figures and two kinds of ceremonial objects (fig. 7, 8) preserved in the Vatican Museums collection. It features a frontal highranking male figure, maybe the so-called Principal Deity of Lambayeque (see above, item MV 66991). He wears a short tunic decorated with stylized zoomorphic motifs (bird or fish?), non-functional shoes with pointed toes (or naked feet), and has S-like patterns on the legs (perhaps snake

55. Desrosiers and Pulini 1992, p. 149 (fig. 88).

56. Jiménez Díaz 2009, p. 176.

57. Desrosiers and Pulini 1992, p. 149.

58. Jiménez Díaz 2009, pp. 175-176 (fig. 123); Ramos Gómez and Blasco Bosqued 1980, pp. 116-118 (tav. XXII).

59. MV 62407, MV 63625, MV 63626, MV 63645, MV 63647, MV 63651, MV 63652, MV 63653, MV 63654, MV 63655, MV 63656, MV 6366o, MV 63662, MV 67012.

6o. These items are available in the online catalogue of the Quai Branly Museum (see collections.quaibranly.fr).

61. The textile collections of the Musée d'ethnographie du Trocadéro (1878-1937) in Paris, as noted above, subsequently flow into those of the Musée de l'Homme in 1937, and finally moved to the Quai Branly Museum - Jacques Chirac in 2004.

62. MQB inv. 71.1914.24.53.1, inv. 71.1914.24.53.2.1-4.

63. MQB inv. 71.1933.0.271.315 X.

64. Édouard Vergne was a medical officer, major in the French military mission in Peru since 1913. Member of the Society of Americanists in France (Paris). He donated to the Trocadéro Museum 53 terracotta pots from Pachacamac in 1914 and 124 terracotta vases and fragments from Huaca Tina (Lambayeque) in 1920. The items then passed into the Musée de l'Homme collections in Paris (Riviale 200o, p. 337).

65. MV 63647, MV 63651, MV 63652, MV 63653, MV 63654, MV 63655, MV 63656, MV 63662.

66. MQB inv. 71.1914.24.53.1, inv. 71.1933.0.271.315 X.

67. MV 63647, MV 63651, MV 63652, MV 63653, MV 63654, MV 63655, MV 63656, MV 63662. 

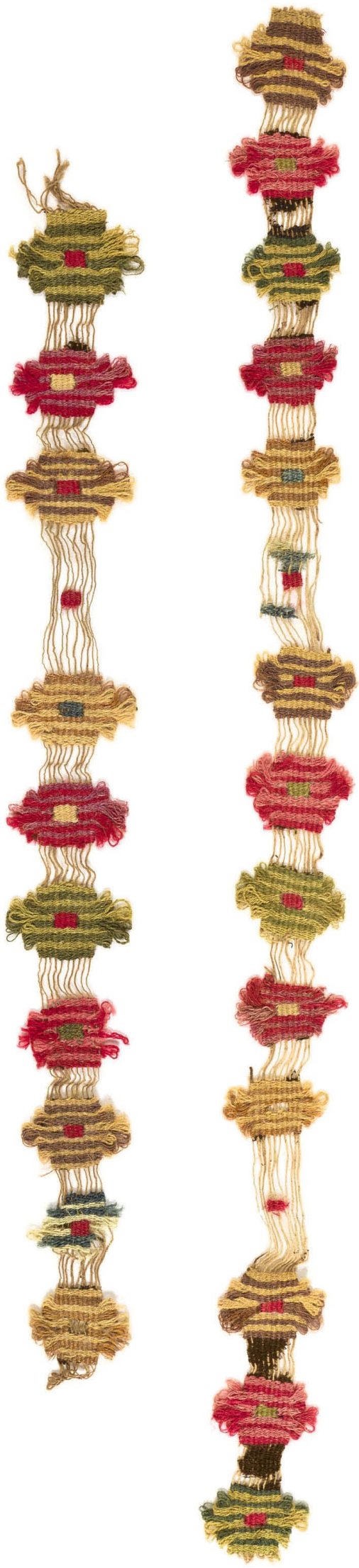

Figure 5. Two fragments of a strip with flower motifs. Lambayeque or Lambayeque/ Chimu, North Coast, Peru, 900-1375 AD. Cotton (warp: S-spun), camelid fiber (weft: 2S-plied); tapestry, 50 x $4 \mathrm{~cm}$ and 40 x $4 \mathrm{~cm}$. MV 63626, Vatican Museums, Vatican City. Foto Copyright (c) Governatorato S.C.V. - Direzione dei Musei.

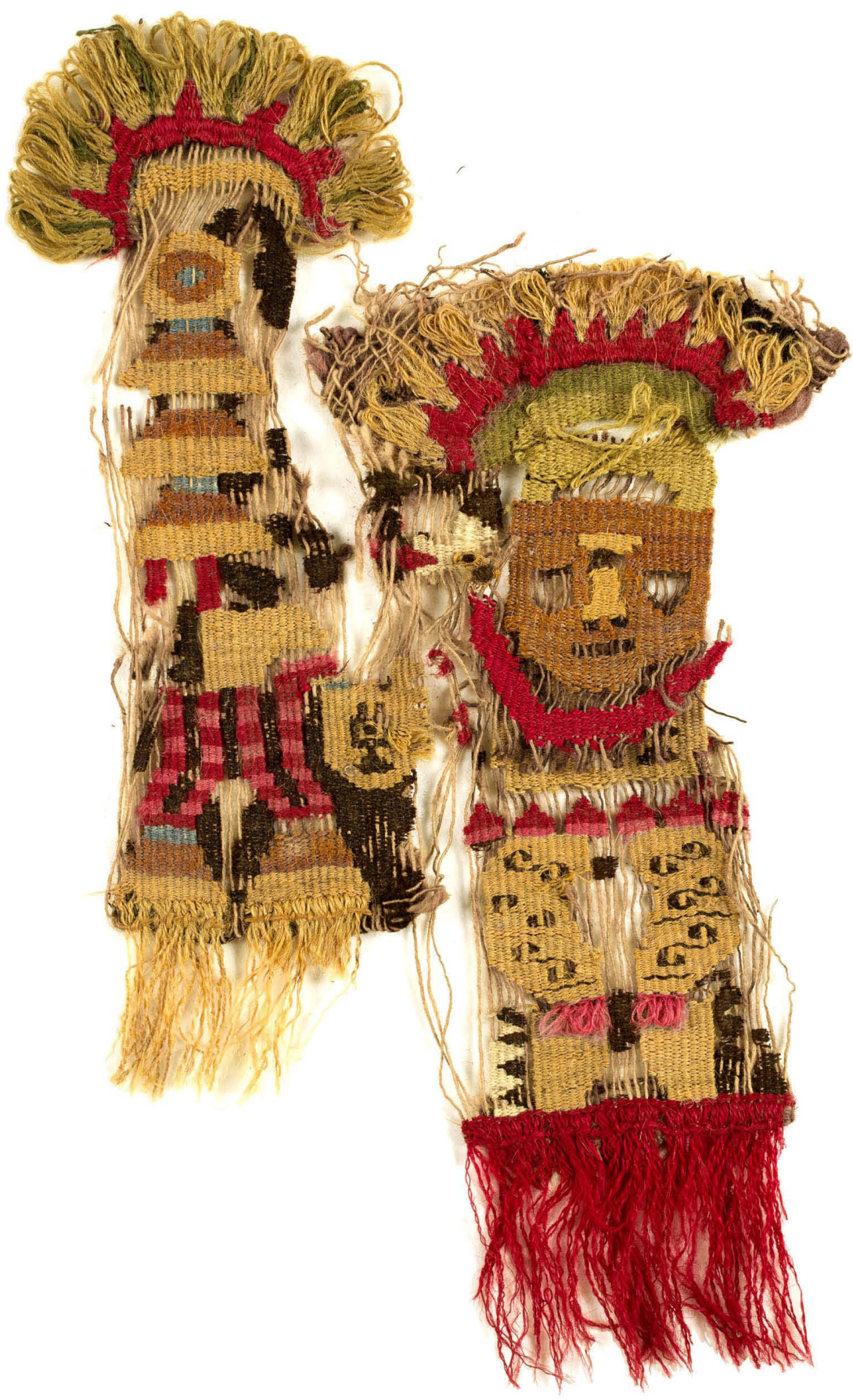

Figure 6. Fragment showing a figure with cerimonial staff. Lambayeque or Lambayeque/Chimu, North Coast, Peru, 1000-1476 AD. Cotton (warps: S-plied for figure, 2Z-plied for scepter), camelid fiber (wefts: 2S-plied for both); tapestry, 16 x $8 \mathrm{~cm}$ (figure), 15 x $6 \mathrm{~cm}$ (scepter). MV 63647, Vatican Museums, Vatican City. Foto Copyright (C) Governatorato S.C.V. - Direzione dei Musei. 

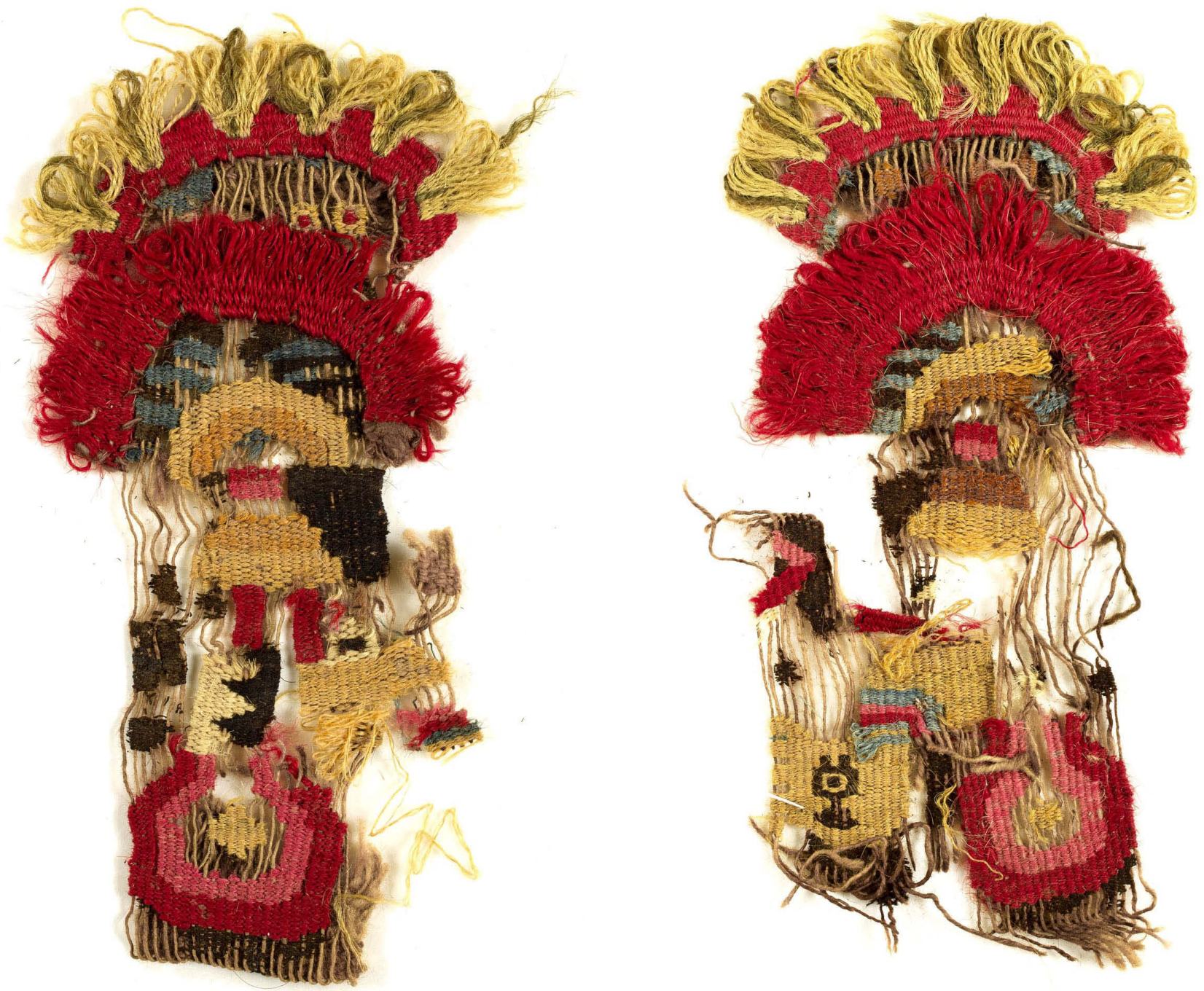

Figures 7-8. Two fragments with depiction of cerimonial object. Lambayeque or Lambayeque/Chimu, North Coast, Peru, $1000-1476$ AD. Cotton (warp: S-plied), camelid fiber (weft: 2S-plied); tapestry, 11 x 6 cm, 13 x $7 \mathrm{~cm}$. MV 63652, MV 63653, Vatican Museums, Vatican City. Foto Copyright (C) Governatorato S.C.V. - Direzione dei Musei.

motifs). He is therefore dressed in full regalia, with all his attributes: an elaborate crescent-like feather headdress; an hourglass nose; a red and white neckpiece in the form of a bicephalic serpent; a ceremonial staff or scepter in the right hand. The figure reflects the traditional iconography of the Northern Peruvian coast during the Late Intermediate Period. The warp yarns of the figure are cotton S-plied, while the weft yarns are camelid fiber plied 2S. The warp yarns of the ceremonial staff are cotton 2Z-plied, while the weft yarns are camelid fiber 2S-plied.

The ceremonial staff or scepter is an insignia of rank that we often find associated with anthropomorphic figures, identified as deities, priests (shamans) or high dignitaries, and depicted on Lambayeque/Sican, Chimu and Chancay textiles from the North and Central coasts ${ }^{68}$. According to Jiménez Díaz ${ }^{69}$ Rowe $^{70}$ and Bjerregaard ${ }^{71}$, these figures with

68. See Amano and Tsunoyama 1979, pp. 68 (fig. 61), 89 (fig. 90); Laurencich Minelli 1984, p. 99 (fig. 102); Desrosiers and Pulini 1992, pp. 149150 (cat. 88-9o); Jiménez Díaz 2009, pp. 169-172 (cat. 119-120), 175-176 (cat. 123); Rowe 1999, pp. 427-431; Stone-Miller 1994a, pp. 126-127 (tav. 37), 249 (cat. 253).

69. Jiménez Díaz 2009, pp. 169, 172.

70. Rowe 1999, pp. 428-430.

71. Bjerregaard et al. 2017, p. 33 . 
large feathered headdresses, dressed with elaborate tunics and loincloths, and holding scepters are more frequently depicted on Lambayeque fabrics dating about the first part of the Late Intermediate Period (1000-1375 AD). One of the two kinds of scepter depicted on the Vatican fragments seems to be an oar-shaped scepter surmounted with a double crescent-like feather headdress (fig. $7, \mathbf{8}$ ). In the Lambayeque culture, the oar was the hallmark of Naymlap, the legendary ruler, and symbolized his arrival from the sea by raft (see above); in the subsequent Chimu culture, indeed, the oarshaped scepter refers to Tacaynamo, mythological founder of the Chimu dynasty ${ }^{72}$.

The Vatican item inv. 63647 is identical to eighteen fragments of two Lambayeque/Chimu textiles ${ }^{73}$ preserved in the Quai Branly Museum at Paris, and is similar to other two beautiful Lambayeque fabrics preserved in Boston, at the Museum of Fine Arts ${ }^{74}$, and in the Montreal Museum of Fine Arts 75 .

The Parisian fragments depict small multi-coloured figures dressed in rich clothes, with an elaborate crescentshaped feathered headdress and an insignia of power in each of their hands (see above, item MV 63626). These fragments were fundamental to get an idea of how the Vatican figures ${ }^{76}$ were supposed to be, and to put back together the missing parts e.g. of tunics, headdresses, neckpieces and implements that each figure holds in his hands.

Similarities between Vatican ${ }^{77}$ and Paris items, as well as the historical fact that some Peruvian fabrics forming the Pfister Collection came from the Musée du Trocadéro in Paris, as we demonstrated in the introduction (see above), show that the Vatican fragments also came probably from the same French museum, and perhaps were originally part of the textile ${ }^{78}$ today preserved in the Quai Branly Museum.

Fragment MV 67012 (fig. 9) depicts a frontal anthropomorphic figure, maybe a high-ranking priest or a nobleman, with a large crescent-like feather headdress carrying hanging objects. It could also depict an important deity of the Lambayeque pantheon. He wears a short red tunic decorated with stylized fishes ${ }^{79}$ and triangles, a loincloth with horizontal multicolor stripes and non-functional shoes with pointed toes or has naked feet. Other attributes of power,

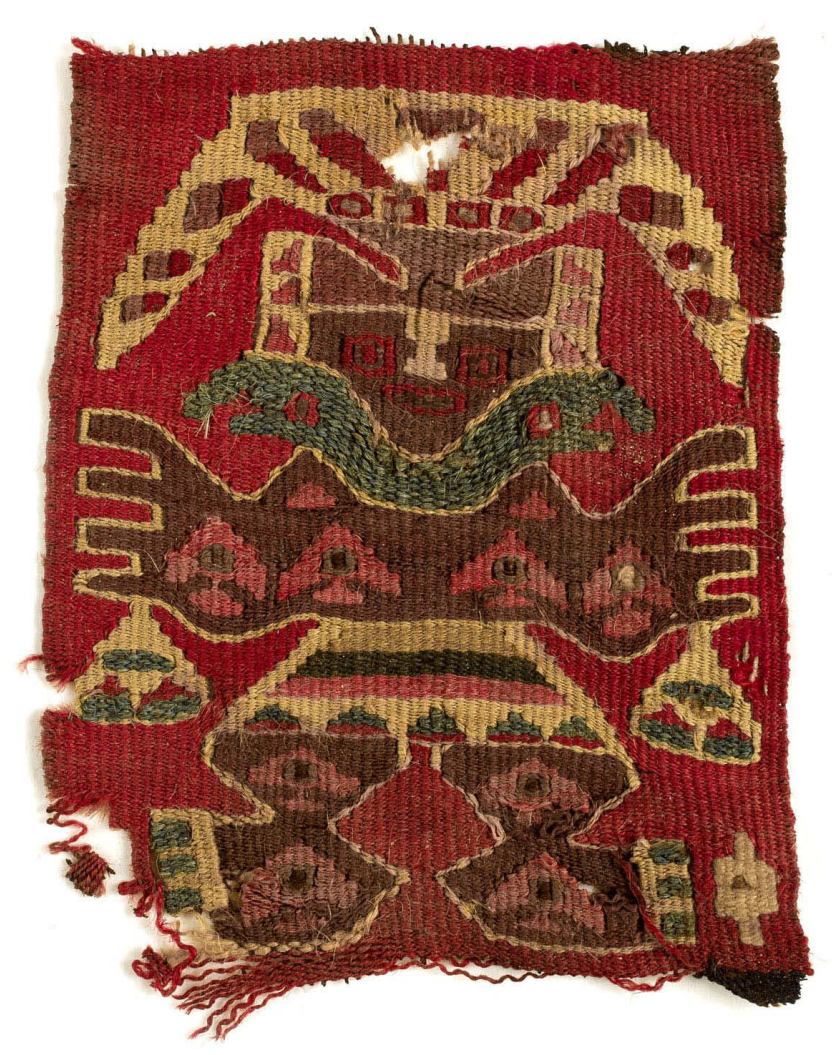

Figure 9. Border fragment showing an anthropomorphic figure. Lambayeque or Chimu, North Coast, Peru, 8oo-1200 AD. Cotton (warp: 2Z-plied), camelid fiber (weft: 2S-plied); tapestry, 8.5 x 6.5 $\mathrm{cm}$. MV 67012, Vatican Museums, Vatican City. Foto Copyright (C) Governatorato S.C.V. - Direzione dei Musei.

considered characteristic of Lambayeque imagery, are the hourglass nose; the green bicephalic serpent neckpiece; and the objects held in each hand, probably in my opinion trophy heads or bags to hold coca leaves ${ }^{80}$. The warp yarns are cotton 2Z-plied, while the weft yarns are camelid fiber 2S-plied.

The figure represented on fragment MV 62407 (fig. 10) is similar in style and iconography to the preceding image featured on item MV 67012 (see above). It depicts a frontal anthropomorphic figure with a tall elaborate crescent-shaped feather headdress; hourglass nose; a tight black neckpiece under the chin in the form of a bicephalic serpent; the figure

72. Fleitman and Baginski 2017, p. 354.

73. MQB inv. 71.1914.24.53.2.1-4, inv. 71.1933.0.271.315.

74. Stone-Miller 1994a, pp. 126-127 (tav. 37).

75. Pimentel 2013, p. 55 (cat. 37).

76. MV 63647, MV 63651, MV 63652, MV 63653, MV 63654, MV 63655, MV 63656, MV 63662.

77. MV 63651, MV 63652, MV 63653, MV 63654, MV 63655, MV 63656, MV 63662.

78. MQB inv. 71.1933.0.271.315.

79. The same motif is depicted on the legs of the figure.

8o. According to Laurencich Minelli (1984, p. 27), bags carrying coca leaves could be symbol of priesthood. 


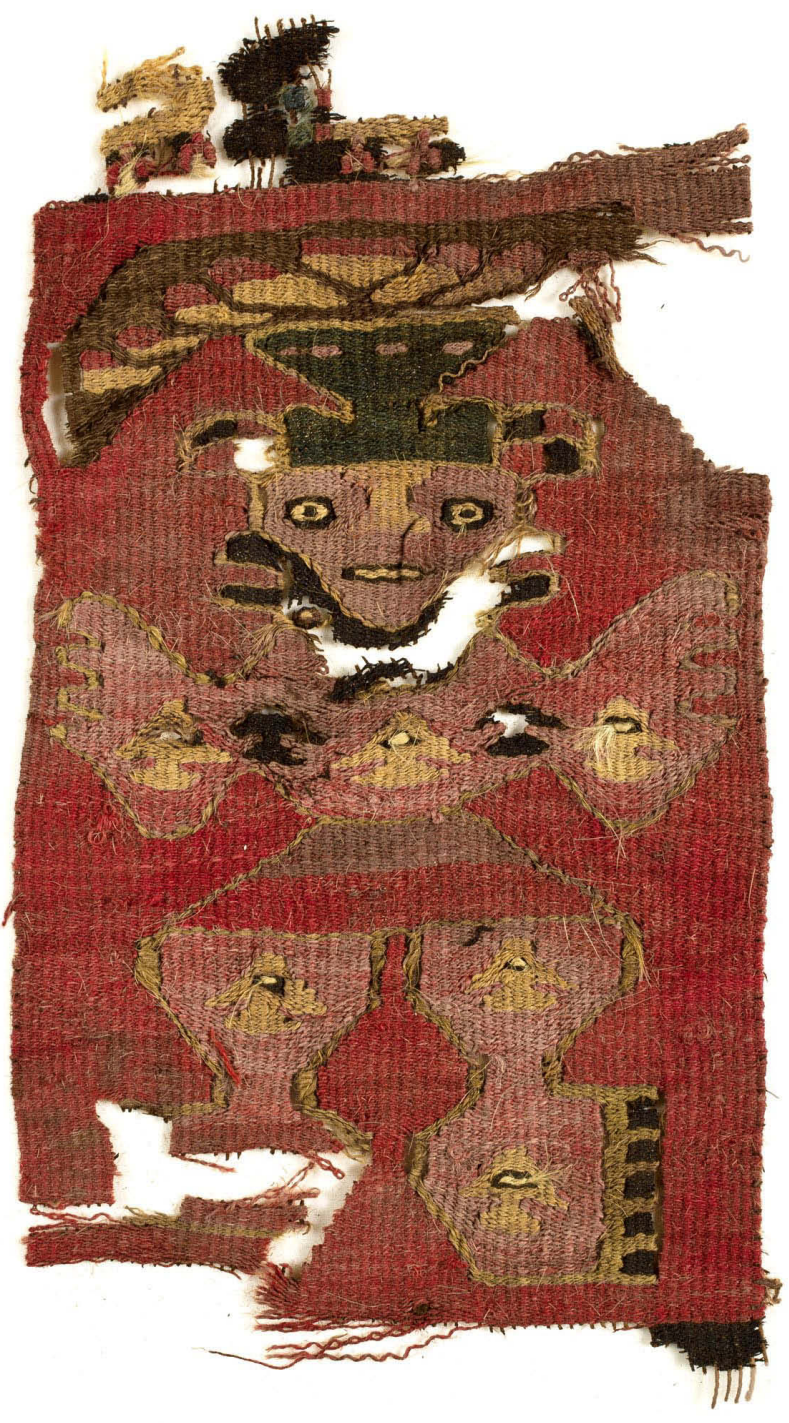

Figure 10. Border fragment showing an anthropomorphic figure. Lambayeque or Chimu, North Coast, Peru, 800-1200 AD. Cotton (warp: 2Z-plied), camelid fiber (weft: 2Z-plied); tapestry, 15 x 7.5 cm. MV 62407, Vatican Museums, Vatican City. Foto Copyright (C) Governatorato S.C.V. - Direzione dei Musei.

does not carry any object in the hands. He wears the same kind of clothes as the figure depicted on MV 67012: a pink tunic decorated with stylized yellow fishes, a loincloth with horizontal multicolor stripes and non-functional shoes with pointed toes, or he has naked feet. In the upper part of the fragment, the yellow body and red feet of two birds, with the green-blue tail of one of them, are partially recognizable (see below). The warp yarns are cotton 2Z-plied, while the weft yarns are camelid fiber 2Z-plied.

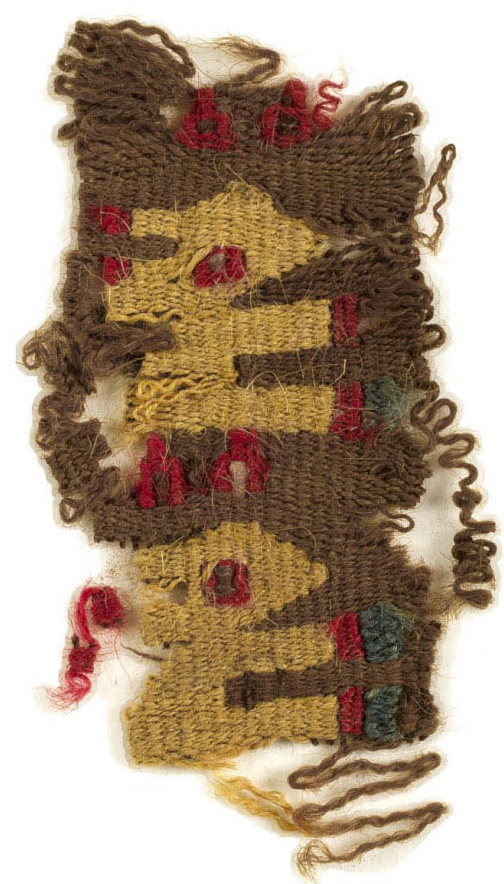

Figure 11. Decorative band fragment showing two birds. Lambayeque or Chimu, North Coast, Peru, 80o-1200 AD. Cotton (warp: 2Z-plied), camelid fiber (weft: 2S-plied); tapestry, 5 × $3 \mathrm{~cm}$. MV 63659, Vatican Museums, Vatican City. Foto Copyright (C) Governatorato S.C.V. - Direzione dei Musei.

The item MV 63659 (fig. 11) is a fragment of a decorative multicolor band that features two stylized yellow birds, depicted in profile and arranged vertically one above the other on a brown background. The eyes, the paws and the tip of the beak are red. The tail (maybe the wings) is shown on a flat surface ("flat perspective") by two yellow elements with red and blue ends. The warp yarns are cotton 2Z-plied, while the weft yarns are camelid fiber 2S-plied. Birds with a similar iconography are published in Jiménez Borja ${ }^{81}$, and are recognizable on some textile fragments preserved in the Quai Branly Museum ${ }^{82}$.

The Paris fragments (see above) and the Vatican item inv. 63659 give us an idea of how the birds of fabric item MV 62407 were supposed to look.

The two figures represented on Vatican fragments (inv. 67012 and inv. 62407) are iconographically comparable to 


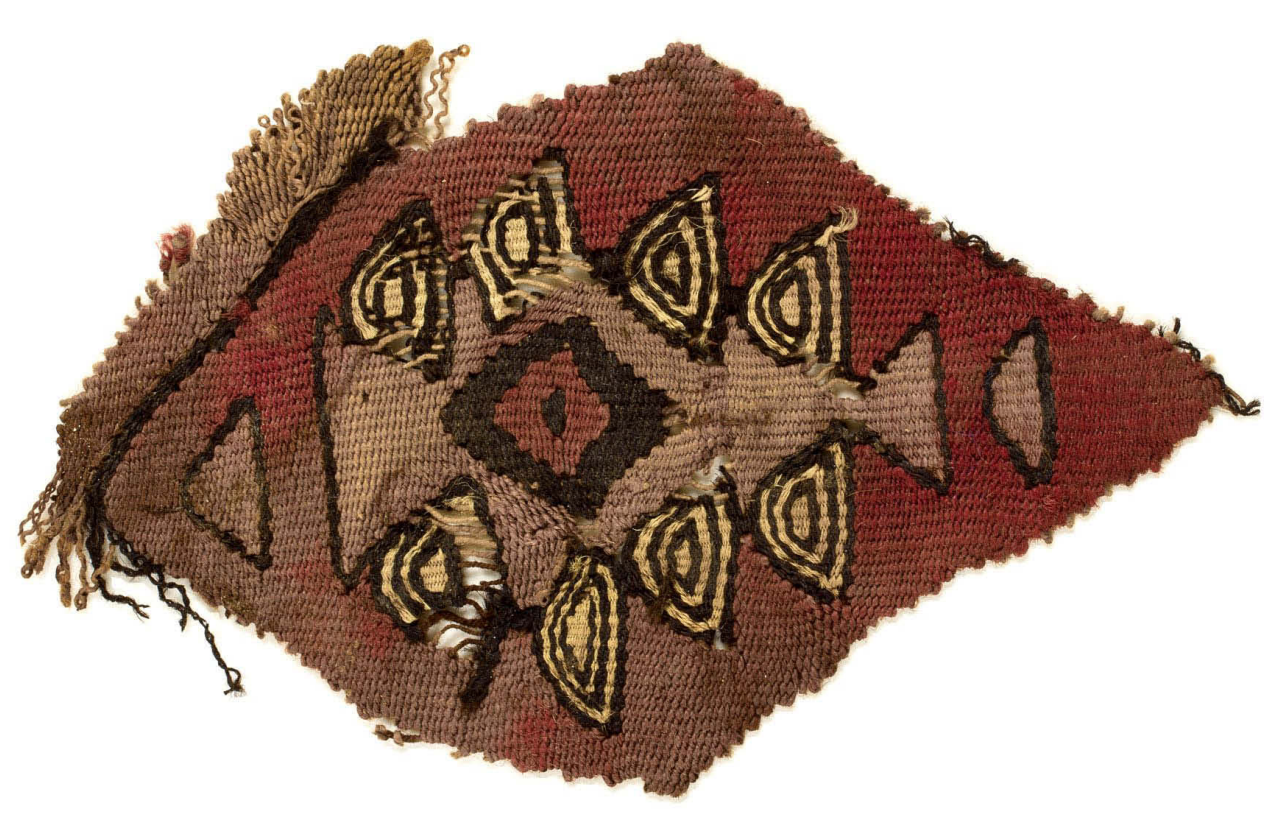

Figure 12. Fragment showing a geometric motif. Chancay, Central Coast, Peru, 1000-1476 AD. Cotton (warp: 2S-plied), camelid fiber (weft: 2S-plied); tapestry, $12 \times 8$ cm. MV 63645, Vatican Museums, Vatican City. Foto Copyright (C) Governatorato S.C.V. - Direzione dei Musei.

the ones depicted on five fragments of two Lambayeque or Chimu items ${ }^{83}$ preserved at the Quai Branly Museum in Paris. The Parisian fragments present a decoration made of small overlapped rectangular panels; each panel contains a frontal anthropomorphic figure with a crescent headdress and an implement in each hand. Furthermore, each panel shows a frame made up of a band of small, very stylized, yellow birds, depicted in profile on a brown background (see above, item MV 63659). Indeed one of the Parisian fragment ${ }^{84}$ reproduces the same design and uses the same colors found in the Vatican item inv. 62407.

We therefore suggest that the two figures depicted on MV 67012 and MV 62407 fragments were probably inserted inside a rectangular panel framed by a decorative band made of small yellow stylized birds (fig. 11).

The undeniable similarity between the two Vatican items (inv. 67012, inv. 62407) and the fragments from Paris, in our view, is not a casuality. We have already mentioned in the introduction that some of the Peruvian textile fragments from the Pfister Collection came from the Musée du Trocadéro in Paris; this could be the case also for the two Vatican fragments, whether they were part of one of the two Quai Branly Museum tapestries.
This conclusion could be confirmed by the very fact that, when the fragments MV 67012 and MV 62407 were kept in the Vatican Apostolic Library (see introduction), they were preserved together and had the same inventory number (inv. 7012) corresponding to the Bontempi BAV inventory catalogue; subsequently, each of them received a new inventory number when they moved to the Vatican Museums collections.

This fragment (fig. 12) is the biggest of twelve incomplete and small-sized fragments which are part of item MV 63645. The warp yarns are cotton $2 S$-plied, while the weft yarns are camelid fiber $2 \mathrm{~S}$-plied. It depicts, on a red Bordeaux color background, a brown jagged rhomboid-shape motif with eight yellow and black appendices along the edge; each appendice is formed by six concentric arc-shaped elements looking like eyes ${ }^{85}$. Three concentric diamonds ${ }^{86}$, two in black and one in red Bordeaux color, are at the center of the motif. Two trapezoidal shapes in brown with a black border decorate both the right and left sides of the main pattern.

Thanks to a comparison with two items preserved in the Quai Branly Museum ${ }^{87}$, it was possible to reconstruct the main pattern (fig. 12) as well as the decorative composition

83. MQB inv. 71.1947.0.5.646.1-5 X, 71.1947.0.5.745 X.

84. One of the four Quai Branly Museum fragments (MQB inv. 71.1947.0.5.646.1-5 X).

85. Similar motifs, presumably simbolic, decorate a Central-Andean coast fabric dating from 1000-1450 AD, but we do not know what they represented and exactly to what style they are to be connected (Jiménez Díaz 2009, p. 276 (cat. 217).

86. According to Amano and Tsunoyama (1979), pp. 73 (fig. 69), 203, the rhombus or diamond pattern could possibly represent a bird eye in a strongly stylized form.

87. MQB inv. 71.1947.0.5.632, 71.1947.0.5.750. 
of the original fabric. The Parisian specimens, indeed, reproduce exactly the motif depicted on the Vatican fragment and use the same colors.

Furthermore, one of the Paris items ${ }^{88}$ gives an idea of how the whole fabric was supposed to be. It probably showed, on a red background, a net decoration formed by lozenges bordered in yellow and black; each lozenge was filled with a rhomboid-shape pattern in yellow, red Bordeaux and black with eight yellow and black appendices. The rhomboid motif could represent a stylized fish caught in the mesh of a net.

Net-shape decorative compositions that look similar to these are found on textiles coming from the North and Central Peruvian coasts dating Late Intermediate Period ${ }^{89}$.

According to the aforementioned examples, therefore, we can assume that most ${ }^{90}$ of the Peruvian textile fragments of the Pfister Collection came from the Musée du Trocadéro in Paris, and were originally and integral part of fabrics now preserved in the Quai Branly Museum. We suggest at the moment that two Vatican fragments (inv. 63626) and other eight fragments ${ }^{91}$ were part of Quai Branly $\mathrm{Mu}-$ seum item inv. 71.1933.0.271.315; three Vatican items (inv. $67012,62407,63659$ ) were part of Quai Branly's fabric inv. 71.1947.0.5.646.1-5; while twelve Vatican fragments (MV 63645) were taken from Quai Branly's tapestry inv. 71.1947.0.5.750. To conclude, the intent of this paper was to offer a first overview of the unkown history of the Vatican Museums pre-Hispanic textiles collection, describing its content in its broad lines and, focusing only on some of its most interesting fabrics. A more complete and detailed catalog of the entire collection will be published shortly in Italy, around fall 2020.

\section{Abbreviations}

ASMV Archivio storico dei Musei Vaticani, Stato della Città del Vaticano (Historical Archives of the Vatican Museums, Vatican City State)

EAAO Enciclopedia Archeologica, Americhe - Oceania, Istituto della Enciclopedia Italiana Giovanni Treccani (ed.), Rome 2004

MNAAH Museo Nacional de Arqueología, Antropología e Historia, Lima

MQB Musée du quai Branly - Jacques Chirac, Paris (Quai Branly Museum, Paris)

\section{Bibliography}

Amano, Yoshitaro, and Yukikhiro Tsunoyama.

1979 Textiles of the Andes. Catalog of the Amano Collection. San Francisco: Heian/Dohosha, 1979.

Biordi, Maurizio,

2005 Museo degli Sguardi. Raccolte Etnografiche di Rimini, Rimini, 2005.

Bjerregaard, Lena.

2016 "Lambayeque-style textiles in the Ethnologisches Museum, Berlin”. In Sophie Desrosiers and Paz Núñez Regueiro (coord.), Colloques. Textiles amérindiens. Recherches récentes du présent au passé et inversement, Nuevo Mundo Mundos Nuevos, 16, 2016.

Bjerregaard, Lena ed., with articles of Beatrix Hoffmann, Ann Peters, Susan Bergh, Jane Feltham, Katalin Nagy, and Gary Urton.

2017 PreColumbian Textiles in the Ethnological Museum in Berlin. Lincoln: Zea Books, 2017. https:// digitalcommons.unl.edu/zeabook/52

Burger, Richard L.

1992 Chavín and the origins of Andean civilization. London: Thames and Hudson, 1992.

D’Harcourt, Raoul.

2008 Les textiles anciens du Pérou et leurs techniques. Paris : Flammarion, 2008. Originally published 1934, Editions Arts et Histoires, Paris.

Desrosiers, Sophie, and Ilaria Pulini.

1992 Musei Civici di Modena. Tessuti precolombiani. Modena: Franco Cosimo Panini, 1992.

Fleitman, Yvonne, and Alisa Baginski.

2017 "Lambayeque Textile Iconography and its Continuity in Chimu and Inca Cultures, and its link to modern Ecuadorian Pujilí Corpus Christi Celebrations". In PreColumbian Textile Conference VII / Jornadas de Textiles PreColombinos VII, Lena Bjerregaard and Ann Peters (ed.), Lincoln: Zea Books, 2017, pp. 34936o. https://digitalcommons.unl.edu/pct7/24

Iklé, Franz.

1930 Über Alt-Peruanische Stickereien des Trocadéro, Paris. St Gallen: Mitteilungen der Ostschweiz. Geogr. Commerz. Gesellschaft, 1930.

Isbell, William $\mathrm{H}$.

1988 City and State in Middle Horizon Huari. In Peruvian Prehistory. An Overview of pre-Inca and Inca Society, edited by R.W. Keatinge, pp. 164 - 189, Cambridge: Cambridge University Press, 1988.

88. MQB inv. 71.1947.0.5.750.

89. See Laurencich Minelli 1984, pp. 84-85 (fig. 85); MNAAH inv. 250416, 250418, 250427; MQB inv. 71.1933.0.271.90.

90. Maybe all of them.

91. MV 63647, MV 63651, MV 63652, MV 63653, MV 63654, MV 63655, MV 63656, MV 63662. 
Jiménez Borja, Arturo, Jorge Zevallos Quiñónez, and James W. Reid.

1987 Chimù. 1st ed. Lima: Banco de Crédito del Perú, 1987.

Jiménez Díaz, María Jesús.

2009 Tradición de tradiciones. Tejidos prehispánicos y virreinales de los Andes. La colleción del Museo de América. Madrid: Ministerio de Educación, Cultura y Deporte, 2009.

Hoces de la Guardia Chellew, Soledad, Paulina Brugnoli, and Carole Sinclaire Aguirre.

2007 Awakhuni. Weaving the History of the Andes. Santander: Museo Chileno de Arte Precolombino, 2007.

King, Heidi.

2012 Peruvian Featherworks. Art of the Precolumbian Era. The Metropolitan Museum of Art, New York, 2012.

Kolata, Alan L.

2004 “Tiwanaku (Tiahuanaco)”. In EAAO, pp. 798-802.

Laurencich Minelli, Laura (editor).

1984 Antichi tessuti peruviani. Tecniche, disegni e simboli. Exhibition catalog (Milan, September - November 1984), Milan: Electa, 1984.

Lavallée, Danièle, and Luis G. Lumbreras.

1985 Les Andes de la Préhistoire aux Incas. Paris: Gallimard (ed.), 1985.

Medina Castro, Maria Ysabel, and Roberto Gheller Doig.

2005 Textiles of Ancient Peru - Tejidos del Perù Antiguo. Lima: Forma e Imagen, 2005.

Petrucci, Valeria, Claudio Cavatrunci, Marco Curatola, Elisabetta De Costanzo, and Luciana Mariotti.

1982 Simbolo e tecnica nei tessuti dell'antico Perù. Exhibition catalog (Rome, February - April 1982), Rome: De Luca (ed.), 1982.

Pimentel, Victor (editor).

2013 Pérou: les royaumes du Soleil et de la Lune. Exhibition catalog (Montreal 2013 - Seattle 2014), Milan: 5

Continents Editions, 2013.
Ramos Gómez, Luis J., and Concepción Blasco Bosqued.

1980 Los tejidos prehispánicos del area central andina en el Museo de América. Madrid: Ministerio de Cultura, 1980 .

Riviale, Pascal.

2000 Los viajeros franceses en busca del Perù antiguo (1821-1914). Lima: Institut français d'études andines (ed.), 2000.

Rowe, Ann P.

1984 Costumes and Featherwork of the Lords of Chimor: Textiles from Peru's North Coast. Washington, DC: The Textile Museum, 1984.

Schaedel, Richard P.

1966 “The Huaca El Dragón”. Journal de la Société des Américanistes 1966, 55 (2): 383-496.

Stone-Miller, Rebecca.

1994a To Weave for the Sun. Ancient Andean Textiles in the Museum of Fine Arts, Boston. London: Thames and Hudson, 1994a.

Stone-Miller, Rebecca.

1994b "Creative Abstractions: Middle Horizon Textiles in the Museum of Fine Arts, Boston". In To Weave for the Sun. Ancient Andean Textiles in the Museum of Fine Arts, Boston, edited by Rebecca Stone-Miller, pp 3542. London: Thames and Hudson, 1994b.

Wester La Torre, Carlos.

2013 "La légende de Naymlap: entre mystère et histoire". In Pérou: les royaumes du Soleil et de la Lune, edited by Victor Pimentel, pp. 108-115, Exhibition catalog (Montreal 2013 - Seattle 2014), Milan: 5 Continents Editions, 2013.

Young-Sánchez, Margaret.

1994 Textile Traditions of the Late Intermediate Period. In To Weave for the Sun. Ancient Andean Textiles in the Museum of Fine Arts, Boston, edited by Rebecca Stone-Miller, pp. 43-50. London: Thames and Hudson, 1994. 